Publisher: Faculty of Agronomy Čačak

\title{
Analysis of factors that influenced consumers' decision to online shop organic food during Covid-19
}

\author{
Maja Ćirići ${ }^{*}$, Svetlana Ignjatijević ${ }^{1}$, Dragan Ilić $^{1}$, Nikola Puvača ${ }^{1}$, Sandra Brkanlić ${ }^{1}$ \\ ${ }^{1}$ Faculty of Economics and Engineering Management in Novi Sad, Cvećarska 2, 21000 Novi Sad \\ *Corresponding author: maja@fimek.edu.rs
}

Received 18 October 2020; Accepted 22 March 2021

\begin{abstract}
A B S T R A C T
There is a significant amount of research in the world on the factors that influence consumers' decision to buy organic food using traditional sales channels. There is also a lot of research related to the factors that influence consumer decision to online shop groceries. However, to our knowledge, there is an extremely modest amount of research on how and why consumers decide to online shop organic food. The Covid-19 pandemic has led to an increase in consumer propensity to shop online, so this topic has gained in importance. Therefore, the aim of this paper was to determine the factors that most influenced consumers' decision to online shop organic food during the Covid-19 Pandemic. The survey was carried out in Serbia by using a questionnaire developed specifically for this purpose, based on questions from 9 relevant surveys in the world. Factor analysis and standard multiple regressions were used to analyze the data obtained from the survey. Four factors have been identified that influenced the online shopping organic food during the Covid-19 Pandemic. The first and most important factor is the Attributes of organic food and deterrents for purchasing. The second important factor is the advantages of online shopping, Covid-19 Pandemic consequences, and organic food labeling. While the third factor (Website characteristics and satisfaction with online shopping) and the fourth factor (Safety of online shopping) are of minor importance. At the end of the paper recommendations for improvement marketing strategy for online selling organic food are given.
\end{abstract}

Keywords: consumer decision, organic food, online shopping, Covid-19 Pandemic.

\section{И 3 В $О$ Д}

У свету постоји значајан број истраживања о факторима који утичу на одлуку потрошача да купују органску храну користећи традиционалне канале продаје. Такође, постоји и много истраживања о факторима који утичу на одлуку потрошача да намирнице купују путем интернета. Међутим, према нашим сазнањима, изузетно је скроман број истраживања о томе како се и зашто потрошачи одлучују да органску храну купују путем интернета. Пандемија Соvid 19 довела је до пораста склоности потрошача ка куповини путем интернета, те је ова тематика добила на значају. Стога је циљ овог рада био да утврди факторе који су највише утицали на одлуку потрошача да купују органску храну путем интернета током пандемије Covid 19. Истраживање је спроведено на територији Србије, коришћењем упитника специјално креираног за потребе овог истраживања, на основу питања из 9 релевантних истраживања у свету. За анализу података добијених истраживањем коришћена је факторска анализа и стандардна вишеструка регресија. Утврђена су четири фактора који су утицали на куповину органске хране путем интернета током пандемије Соvіd 19. Први и најважнији фактор су својства органске хране и чиниоци који потрошаче одвраћају од куповине органске хране. Други важан фактор су предности куповине путем интернета, последице пандемије Сovid 19 и означавање органске хране. Док су трећи фактор (карктеристике шеб сајта и задовољство куповином путем инетрнета) и четврти фактор (безбедност куповине путем интернета) од мањег значаја. На крају рада дате су препоруке за побољшање маркетинг стратегије за продају органске хране путем интернета.

Кључне речи: одлука потрошача, органска храна, куповина путем интернета, Covid 19 пандемија.

\section{Introduction}

A large number of researchers in the analysis of the factors that influence consumer decision-making on the purchase of organic food have dealt with the motives of buying organic food and consumer attitudes about organic food. One of the most common consumer motives in buying organic food is health issues, so the health attributes of organic food stand out as very important in the consumer decision-making process (Gil et al., 2000; Padel and Foster, 2005; Lee and Yun, 2015; Kapuge, 2016; Oroian et al., 2017; Nagy-Pércsi and Fogarassy, 2019). There are also studies that, in addition to caring for human health, cite the protection of the environment and animal welfare as a motive for buying organic food (Magnusson et al., 2003; Basha et al., 2015). Buying decisions on organic food are driven largely by characteristics, such as freshness and taste (Rana and Paul, 2017; Ellison et al., 2016). According to Stoleru et al. (2019) quality and sensory attributes (appearance, taste, and flavor) are associated with organic technology. It should be emphasized that buying products online is associated with the risk of misjudging some products. Some online product images are of poor quality or there are no product images at all, which makes it difficult to estimate the 
size, weight, and overall value of the product when purchased online. Wägeli et al. (2016) found that as consumers become more aware of the growing environment and production processes of locally produced food and the fact that short-distance transportation could keep food fresh, they prefer to buy local organic food. Padel and Foster (2005) point out that the main motives for organic food purchasing are health consciousness and social aspects like support of local farming, fair trade and - further down the scale environmental protection. Quality labels have also been highlighted as significant in consumer behavior when buying organic food (Bryła, 2018; Nagy-Pércsi and Fogarassy, 2019; Rana and Paul, 2017; Drexler et al., 2018). Strengthening the display of food quality signs and labels and improving the authenticity, richness and legibility of food quality information can help consumers form better perceptions of quality and risk (Liu and Zheng, 2019). According to Pham et al. (2019) food safety concern, health consciousness and media exposure to food messages influence consumer attitude towards organic food. While consumers' environmental concern and food taste are of less importance in shaping their attitudes. The authors also pointed out that the attitudes of consumers of organic food and their purchase intention are significantly influenced barriers (i.e. high price, inadequate availability, poor labeling and extra time required) (Nagy-Pércsi and Fogarassy, 2019), and also that organic food consumers are not very interested in branded products, but rather they are looking for product groups or opting for system characteristics related to product sales that are based on consumer confidence. However, there are also research results that show that for both organic private label brands and organic national brands, brand equity positively influences organic brand consumption and organic consumption behavior (Reinders and Bartels, 2017). Trust emerges as an important factor in deciding where to buy organic food and according to Padel and Foster (2005) results consumers have less trust in supermarkets and large corporations. The higher trust of specialist organic or local shops over supermarkets may be a reflection of wider anxieties about the food system. In relation to organic products their research indicates that there is a lack of knowledge about certification and labeling and about the guarantee that organic standards really offer to consumers. In addition, there is confusion among consumers when it comes to the very concept of "organic food", which also reflects the need to better inform consumers about the method of certification and labeling (Aarset et al., 2004).

Price is a factor that cannot be ignored because it is usually the reason why consumers buy less organic food (Marian et al., 2014). Aschemann-Witzel and Zielke (2017) have found that price is the biggest barrier to buying organic food. Organic food consumers are willing to pay a premium of about $30 \%$ (ranging from $0 \%$ to $105 \%$ ) depending on the product category and consumer segment. Organic consumers' price sensitivity is relatively lower than that of occasional or nonorganic consumers. Since the price elasticity of organic food is a lot higher than for conventional food, the price reduction can have a positive effect on demand (Marian et al., 2014). In addition to the price, one of the biggest barriers in buying organic food is the lack of availability of organic products (Lea and
Worsley, 2005; Zanoli and Naspetti, 2002; Hughner et al., 2007).

Recent studies found that subjective norms and social values (which are created under the influence of reference groups, such as family, friends, etc.) positively influence the consumers' intention to buy organic products (Khan and Mohsin, 2017; Rahnama, 2017; Aertsens et al., 2009). However, some studies have not found any relationship between social value and green consumption behavior (Lin and Huang, 2012).

Khan and Mohsin (2017) found that emotions can determine the purchasing behavior of organic meat. Among the three emotions studied (fear, guilt, and empathy), especially "fear" impacts on consumers' purchase decisions. Consumers experience positive emotions like feeling good, satisfied, well-being, and comfort while choosing or consuming green products over conventional ones. Recently it is established that these emotional values lead toward organic food consumption (Testa et al., 2019).

In analyzing the factors that influence consumer decision to shop online, we focused on research online grocery shopping. Morganosky and Cude (2000) have determined that they are convenient and saving time primary consumer motivation for buying groceries online. Whereby is a time-saver a result of not traveling to and from the store, rather than a decrease in shopping time? Besides, as a reason for online shopping they state and physical constraints (difficulty driving and lifting groceries) that make it difficult for them to shop at grocery stores Also, the reason for online shopping can be to avoid grocery shopper stressors such as problems of crowding and standing in line. "Retailers must, however, be careful that in-store stressors are not replaced with parallel online stressors such as being unable to access the Web site, long delays in completing online orders, inconsistencies in the items available online, mistakes in filling orders, and the hassle of returning merchandise" (Morganosky and Cude, 2000). Sreeram et al. (2017) have revealed that a large proportion of consumers consider delivery charges a major deterrent of online grocery shopping. Huang and Oppewal (2006) assert that online shopping preferences are affected by perceived cost, perceived convenience, perceived enjoyment, and perceived risk. They conclude that saving time is a more important factor for consumers than delivery costs (delivery charge). Perceived risk, particularly concerning purchasing food from grocery e-retailers, is of vital importance (Morganosky and Cude, 2000; Huang and Oppewal, 2006; Mortimer et al., 2016). A customer who trusts the online grocery retailer will perceive less risk during online shopping, whereas a less trusting customer will perceive higher risk (Mortimer et al., 2016). Sreeram et al. (2017) concluded that product assortment, social influence, entertainment value, design aesthetics, economic value, physical effort, and time pressure have direct or indirect a positive impact on consumer behavioral intention to use online grocery shopping. Online consumers see design and aesthetics as very important reasons for using online shopping websites (Huang and Oppewal, 2006). Product assortments in color, design, or price on the shopping websites can increase web browsing gathering information or comparison shopping (Pham et al., 2019). Product assortment in the website encourages consumer buying behavior, which results in gathering 
more information about the product and finally impulsive buying behavior (Park et al., 2012). A lot of Indian shoppers use online shopping carts to compare prices of similar products with no intention to purchase (45\%). They also stop short of clicking 'purchase' as they are put off from higher than expected shipping costs $(54 \%)$, or face issues with out-of-stock items (42\%). Social communities and forums influence consumer attitude in both cognitive and affective extents. Consumers do participate in online social groups, by observing others' knowledge and experience and through interaction ultimately can affect their attitude and beliefs. Social recommendations, rating and reviews are very important (Akram et al. 2019).

According to Aertsens et al. (2009) sometimes occasions occur and people may be triggered to step out of their automated routine. In such circumstances, they may step out of routine behavior and be motivated to reason and consider a wider range of possibilities than they usually do. In such cases, especially when consumers look for safety and/or quality buying organic food may be considered. For example, dioxin and BSE food scares in Europe between 1995 and 2002, have caused some consumers to switch to organic food consumption. In the case of the crisis in the meat industry (mad cow disease), consumers felt that their health was endangered by consuming meat, so the consumption of organic meat increased (Pennings et al., 2002). Given the above reactions of consumers in crises in the past, it is expected that factors such as fear for their health and the health of family members, limited movement, market closures and limited operation of shops during the Covid-19 Pandemic will affect consumer decision to shop online organic food. So, the purpose of this study was to determine the factors that most influenced consumers' decision to buy organic food online during the Covid-19 Pandemic. Obtained results can give us an insight to consumers attitudes toward online shopping organic food, and able us to give some recommendation for improvement marketing strategy for online selling organic food in the changed circumstances caused by Covid-19 Pandemic.

\section{Materials and methods}

The survey instrument was questioner and questions were created especially for this research. The group of questions provided insight into consumer attitudes about the importance of various factors in their decision to online shop organic food. In particular, we conceptualized a group of 36 statements/factors that were to be rated on the Likert scale with a score from 1 to 5 (1 least important and 5 most important factors for online shopping organic food). When creating the statements, we took into account the views of other researchers as well (Bryła, 2018; AschemannWitzel and Zielke, 2017; Nagy-Pércsi and Fogarassy, 2019; Rana and Paul, 2017; Aertsens et al., 2009; Lin and Huang, 2012; Morganosky and Cude, 2000; Sreeram et al., 2017; Akram et al., 2019) which indicated the factors that influence consumers decision to purchase organic food, as well as the factors that affect the online shopping of groceries. Besides, we have included findings specific to the outbreak of the Covid-19 Pandemic, taking into account the measures implemented in Serbia in the fight against the Covid-19 Pandemic. The research was conducted at the beginning of April 2020, when a state of emergency was introduced in Serbia due to the Covid-19 Pandemic. At that time, measures were in force: limited movement of people, suspension of public transport, the closing of markets, and limitation of working hours of specialized stores and supermarkets.

The total number of distributed questionnaires was 1500 , to which $1275 \quad(85 \%)$ respondents answered. Respondents, residents of cities in Serbia (1022) were singled out from that number, considering that the residents of cities in Serbia were most affected by the measures due to the Covid-19 Pandemic. Besides, we had in mind that the great awareness about the importance of organic food is existing among consumers living in urban areas. As well as, the greatest demand for organic products is in bigger cities (Dašić et al., 2019). That number of respondents was narrowed down to those who bought organic food online during the Covid-19 Pandemic. Their number was 90 ( $8.8 \%$ of city respondents). Thus, we obtained a sample of those respondents who bought organic food online during the Covid-19 Pandemic. We selected the respondents using the "snowball" method, by sending the link with the questionnaire to the email addresses of a large number of respondents with a request to forward the link. This method enabled as many respondents as possible to be included in the research especially because the online purchases of organic food are on a low awareness within consumers (Venter et al., 2011) and there is not so much data in the scientific literature in that field.

Data processing was performed using the SPSS program for statistical data processing. Factor analysis and standard multiple regressions were used to analyze the phenomena in detail. The purpose of our research problem was to find an equation that best predicts the dependent variable as a linear function of the independent variables therefore the multiple regression was applied (Wekeza and Sibanda, 2019).

\section{Results and discussions}

In the research the attitudes of consumers about the importance of certain factors for their decision to buy organic food online during the Covid-19 Pandemic were measured. We performed a unified factor analysis, where we took into account 36 claims. The data were processed in the statistical package SPSS for Windows, version 22 . To examine the latent structure of the Questionnaire for measuring consumer attitudes about the factors influencing their decision to buy organic food during Covid-19, factor analysis was applied the main components method. As the KaiserMeyer-Olkin sample adequacy measure was satisfactorily high $(\mathrm{KMO}=0.783)$ and the Bartlett sphericity test was significant $\left(\chi^{2}=13102.431, P<\right.$ $0.000)$, the analysis was approached. Using Cattell's scree criteria, 4 factors were retained. To achieve a simple structure the factors were rotated in Varimax rotation. Factor scores were established, and we calculated the Cronbach's reliability coefficient for each factor. Cronbach's reliability coefficients are: 0.962; $0.944 ; 0.772$ and 0.871 .

Taking into account the saturations shown in the matrix of the circuit (Table 1), the obtained factors were interpreted as, i.e. grouped into 4 units: The first factor is the advantages of online shopping, Covid-19 Pandemic consequences, and organic food labeling. The second factor is the attributes of organic food and 
deterrents for purchasing. The third factor is Website characteristics and satisfaction with online shopping.
The fourth factor is the Safety of online shopping.

Table 1.

Exploratory factor analysis for factors that influence online shopping organic food

\begin{tabular}{|c|c|c|c|c|}
\hline & & Components & & \\
\hline $\begin{array}{l}\text { Factors that influenced consumer decision to } \\
\text { online shop organic food }\end{array}$ & $\begin{array}{l}\text { Advantages of } \\
\text { online } \\
\text { shopping, } \\
\text { pandemic } \\
\text { Covid-19 } \\
\text { consequences } \\
\text { and organic } \\
\text { food labeling }\end{array}$ & $\begin{array}{l}\text { Attributes of } \\
\text { organic food } \\
\text { and } \\
\text { deterrents for } \\
\text { purchasing }\end{array}$ & $\begin{array}{l}\text { Website } \\
\text { characteristic } \\
\text { sand } \\
\text { satisfaction } \\
\text { with online } \\
\text { shopping }\end{array}$ & $\begin{array}{l}\text { Safety of } \\
\text { online } \\
\text { shopping }\end{array}$ \\
\hline Delivery charges & 0.787 & & & \\
\hline $\begin{array}{l}\text { Organic food deliverer has adequate protective } \\
\text { equipment }\end{array}$ & 0.774 & & & \\
\hline Less exposure organic food to more people & 0.757 & & & \\
\hline Time of delivery & 0.756 & & & \\
\hline Quality signs of organic food & 0.753 & & & \\
\hline Time-saving of online shopping & 0.746 & & & \\
\hline Accuracy of delivery & 0.745 & & & \\
\hline Brand of organic food & 0.735 & & & \\
\hline Restrictions of movements & 0.724 & & & \\
\hline Market closure & 0.702 & & & \\
\hline Effort of getting items back home & 0.699 & & & \\
\hline Easiness to find information & 0.694 & & & \\
\hline Effort of going to a store & 0.685 & & & \\
\hline Fear of contact with people in the store & 0.614 & & & \\
\hline $\begin{array}{l}\text { Availability of a wide assortment of organic } \\
\text { food }\end{array}$ & 0.614 & & & \\
\hline Trust in online retailer & 0.604 & & & 0.522 \\
\hline $\begin{array}{l}\text { Trust in health-safe transportation organic } \\
\text { food }\end{array}$ & 0.597 & & & 0.472 \\
\hline Easiness to place an order & 0.594 & & & 0.511 \\
\hline Freshness of organic food & & 0.796 & & \\
\hline Knowledge about producer of organic food & & 0.768 & & \\
\hline Satisfaction with conventional food & & 0.755 & & \\
\hline Local origin of organic food & & 0.723 & & \\
\hline Health attributes of organic food & & 0.721 & & \\
\hline Trust in organic certification process & & 0.718 & & \\
\hline Possibility of payment upon delivery & & 0.662 & & \\
\hline Card payment option & & 0.656 & & \\
\hline Price of organic food & & 0.654 & & \\
\hline Real image of organic food & & 0.626 & & \\
\hline Payment to a bank account & & 0.622 & & \\
\hline Taste of organic food & & 0.576 & & \\
\hline Environmental and animal welfare care & & 0.566 & & \\
\hline $\begin{array}{l}\text { Reviews and recommendations of other } \\
\text { consumers }\end{array}$ & & & 0.578 & \\
\hline $\begin{array}{l}\text { Design and aesthetic of online shopping } \\
\text { websites }\end{array}$ & & & 0.562 & \\
\hline Satisfaction with online shopping & & & 0.507 & \\
\hline Safety of credit card data & & & & 0.729 \\
\hline Safety of personal data & & & & 0.508 \\
\hline Initial Eigenvalues & 20.485 & 4.315 & 3.398 & 1.925 \\
\hline Percentage of variation Cumulative & 42.68 & 8.99 & 7.079 & 4.011 \\
\hline Cumulative Percentage & 42.68 & 51.668 & 58.747 & 62.757 \\
\hline Crombach’s alphas & 0.962 & 0.944 & 0.772 & 0.871 \\
\hline
\end{tabular}

Taking into account the saturation shown in the circuit matrix (Table 1), the obtained factors are grouped into 4 units. The first factor accounts for $42.68 \%$ of the variance in the model (Advantages of 
online shopping, Covid-19 Pandemic consequences, and organic food labeling), the second factor for $8.99 \%$ of the variance (Attributes of organic food and deterrents for purchasing), the third factor for $7.079 \%$ of the variance (Website characteristics and satisfaction with online shopping) and the fourth factor accounts for $4.01 \%$ of the variance (Safety of online shopping). Squared factor loadings:

In the first factor of a total of 18 items three statements, with the highest factor loadings $(0.787$, 0.774 and 0.757 ), most accurately describe it. The squares of the indicated correlation coefficients represent the variance proportions of certain variables that are attributed to the effect of a given factor. The squared factor loadings, for the most significant statements within the first factor, explain $61.94 \%$, $59.91 \%$, and $57.30 \%$ of the variance of the factor named Advantages of online shopping, Covid-19 Pandemic consequences, and organic food labeling.

Within the second factor of 13 items three statements, with the factor loadings (from 0.755, 0.768, 0.796) accurately describe it. The squared factor loadings, for the two most significant statements, explain $60.68 \%, 57 \%, 58.98 \%$, and $63.36 \%$ of the variance of the factor named Attributes of organic food and deterrents for purchasing.

Within the third factor of 3 items $(0.578,0.562$, and 0.507 ) that explain $33.41 \%, 31.58 \%$ and $25.70 \%$ of the variance of the factor named Website characteristics and satisfaction with online shopping.

In the fourth factor 2 statements, with the highest factor loadings (0.472 to 0.729) describe it most accurately. The squared factor loadings, for the most significant statements, within the fourth factor explain 22.28 to 53.14 of the variance of the factor named Safety of online shopping.

To define the impact of 4 factors obtained after factor analysis, we conducted a standard multiple linear regression on the online purchase of organic food during the Covid-19 Pandemic. Testing was performed before the regression was performed. It was first checked whether there was a correlation between the variables in the model. All independents correlate with the dependent, and there is no independent that strongly correlates with the dependent (over 0.7). After that, the diagnostics of the collinearity of the variables was performed.

The tolerance value is greater than 0.7 , and the VIF value is not greater than 10 , which confirms that there is no multicollinearity. After that, the evaluation of the model was started. The coefficient of determination (R$\mathrm{Sq}$ ) has a value of 0.65 , which indicates that the above factors with $65 \%$ affect the online purchase of organic food during Covid-19. Adjusted R Square, which better explains the model, is $=0.634$, so we correct the influence of factors on $63.4 \%$ of the explanation of the model by the identified factors. The empirical level of the $\mathrm{F}$ distribution is 39.550 and indicates that the high value of the $\mathrm{F}$ distribution is not random and that the regression equation is applicable when predicting the consumer decision to online shop organic food during the Covid-19 Pandemic by the influence of defined factors. In the following, we measured how much each variable in the model contributed to the prediction of the dependent variable. Analysis of partial regression coefficients for predictor variables in multiple regression shows that statistically significant unique specific contributions F1 - Advantages of online shopping, Covid-19 Pandemic consequences, and organic food labeling and F2 - Attributes of organic food and deterrents for purchasing in predicting variability online shopping organic food during Covid19. Standardized B coefficients show: in a situation where F2-F4 is constant, an increase in F1 per unit of measure leads to an increase in online shopping organic food during Covid-19 by 0.372 , with this impact being statistically significant. By analogy, we conclude that at constant F1, F3, and F4, an increase in F2 per unit of measure leads to an increase in online shopping organic food during Covid-19 by 0.620 and is statistically significant impact. Factors F3 and F4 have a weak influence and in situations of constant other factors contribute to the increase of online shopping organic food during Covid-19 by 0.099 and 0.089 respectively and these influences are not statistically significant. The order of action of the predictor variables in the model is shown below: The first predictor F1 explains with 29.4\% (Adjusted R Square = 0.294) online shopping organic food; when we introduce the second predictor F2 into the model, a total of $63 \%$ is explained and each subsequent predictor increases the explanation of variability in about the online shopping organic food during Covid19 by only $1 \%$. Thus, the first and strongest influence on the online shopping organic food in the conditions of Covid-19 is F2, then F1, and then both F3 and F4.

Table 2.

Standard multiple regression

\begin{tabular}{ccc}
\hline Factor name & Unstandardized coefficients (Std. error) & Standardized coefficients \\
\hline (Constant) & $1.002(0.000)$ & 0.375 \\
\hline F1 & $0.372^{* *}(0.069)$ & 0.689 \\
\hline F2 & $0.620^{* *}(0.074)$ & 0.084 \\
\hline F3 & $0.099(0.087)$ & 0.086 \\
\hline F4 & $0.089(0.079)$ & \\
\hline \multicolumn{3}{l}{}
\end{tabular}

The first factor shows us that the consequences of the Covid-19 Pandemic are interrelated with the benefits of online shopping. Namely, due to the increased fear of consumers from contact with other people and possible contamination of food in stores, as well as due to limited movement, there was a greater need for online shopping and delivery of organic food to the home address. This is also in line with research by Morganosky and Cude (2000) according to which physical constraints and avoiding grocery shopper stressors can be stimulants for online shopping. Besides, within this factor, the importance of the 
delivery charge is especially emphasized. This is explained by the fact that the cost of food delivery in Serbia is relatively high compared to the price they pay for organic food, so they represent a criterion that is important for the consumer when deciding whether to buy organic food online. The result is in line with research (Morganosky and Cude, 2000) according to whom delivery charges are a major deterrent of online grocery shopping. Therefore, delivery costs should be considered as a very important factor when sellers are looking for a way to improve the sale of organic food online. It is important to emphasize that the first factor, in addition to the above, shows the connection between the consequences of the Covid-19 Pandemic and online shopping and product labeling. Namely, in the case of online shopping when consumers cannot touch and try the product, as well as in the case of heightened fear caused by the Covid-19 Pandemic, quality labels and product brands become important to them in making decisions about buying organic food online. This is in line with the research of Bryła (2018) which pointed out the importance of quality signs for online shopping. The second factor shows that consumers, when making a decision to buy organic food online, on the one hand, have important characteristics of organic food (fresh, healthy, of local origin) that motivate them to buy. On the other hand, it is important to them whether there are barriers to buying organic food, such as knowledge and trust in the producer, satisfaction with the existing conventional product, price, and method of payment. Numerous researches that we have mentioned in the introduction indicate the importance of freshness, health attributes, taste, local origin, etc. for the purchase of organic products (Gil et al., 2000; Padel and Foster, 2005; Lee and Yun, 2015; Kapuge, 2016; Oroian et al., 2017; Nagy-Pércsi and Fogarassy, 2019; Rana and Paul, 2017; Ellison et al., 2016). As the lack of knowledge prevents consumers from distinguishing organic from conventional products (Gleim, 2013), the knowledge of producers and the trust that consumers have in producers is one of the important factors when deciding to buy organic food online. Low variety of fresh organic products; high price; satisfaction with conventional food, are some of the barriers to buying organic food identified by Fotopoulos et al. (2003). Hughner et al. (2007) pointed out in their paper that some of the motives for purchasing organic food are: health concern; superior test; concern for the environment; food safety; support the local economy. While some of the deterrents for purchasing are: high prices premiums; skepticism towards organic food label; satisfaction with conventional food etc. This largely coincides with the statements that make up (explain) this factor. Given that the freshness of the product stands out as the most important statements of this factor, and that in online shopping it is more difficult to assess how fresh the product is, this result is important in creating an online offer of organic food. Namely, sellers in the online offer of organic food should emphasize the shelf life of the organic product. The third factor indicates that the design and aesthetics of online shopping websites, and the ratings and recommendations of consumers that they leave on the site are related to satisfaction during online shopping. Morganoski and Cude (2000) indicated that consumers will have a great preference for online shopping and have a higher degree of satisfaction with online shopping. In addition, the assessments and recommendations of other consumers are reflected in both the affective and cognitive components of consumer attitudes (Akram et al., 2019) as well as emotions consumers (Aertsens et al., 2009), i.e., consumer satisfaction in online shopping in this case. The fourth factor indicates the importance of personal data security and card payments online. Regression analysis showed that for the online shopping organic food, the attitude of consumers about the characteristics of organic food and the existence of barriers to their purchase is important in the first place. So in order to shop organic food online, there must be a positive consumer attitude about organic food and as few deterrents as possible for their purchase. Then, it is very important that there is a welldeveloped system of delivery of organic products that are shopped online, as well as proper labeling of organic products. In addition, the impact of the Covid19 Pandemic has been shown to affect the online purchase of organic food while the factors related to the characteristics of the website and satisfaction with online shopping have proven to be less important. This can be explained by the fact that the main reason for online shopping organic food was the opportunity to buy fresh, healthy food without being at health risk from the Covid-19, which makes it less important to them how the site is designed and whether they will feel satisfied during the online shopping. Also, trust in the security of personal data and card payments were not important because there are other ways of payment, such as cash on delivery.

\section{Conclusions}

The results of the research showed that during the Covid-19 Pandemic factors that influenced consumers' decision to online shop organic food were: in the first place Attributes of organic food and deterrents for purchasing, then Advantages of online shopping, consequences of Covid-19 Pandemic, and organic food labeling. While Website characteristics and satisfaction with online shopping, as well as Safety of online shopping were of less importance. The first factor indicated that in the online shopping organic food, consumers were guided primarily by the characteristics of the organic food themselves and the benefits they can achieve by consuming organic food compared to conventional food. This indicates that if producers and sellers want to improve online shopping, they should primarily focus on showing consumers the attributes of organic food in the online offer in the best possible way. Given that the Freshness feature stood out as very important in explaining the first factor, the recommendation is to mark the shelf life of the product in the online offer. It is also important to show as realistic a picture of the product as possible. Also, given the importance that consumers attach to the knowledge of producers, it is very important to implement promotional activities that would better position producers in the minds of consumers. Another factor pointed out how fears and restrictions on the movement of people and the operation of stores during the Covid-19 Pandemic were reflected in the recognition of the benefits that online shopping has. The advantages were primarily the possibility of home delivery, less contact of food with other consumers, and the ability to bring larger quantities of food without personal effort. What has been noticed is that delivery 
costs are very important for consumers in Serbia, so producers and sellers of organic food should find a financial account that would allow them to reduce these costs. Besides, it has been found that in the case of present fear and online shopping, product quality labels gain in importance. Therefore, it is recommended for sellers that the quality labels and product brands be especially emphasized in the online offer of organic food. The third factor did not contribute much to the online purchase of organic food, as consumers were more guided by their knowledge and fear factors than by enjoying the online shopping and recommendations of other consumers. The fourth factor did not contribute much online shopping, given that most sellers in Serbia have the option of paying by cash on delivery.

\section{Acknowledgment}

This paper is a result of the research within the project "Enhancing the competitiveness of traditional food products in the function of sustainable development of AP Vojvodina", No. 142-4512505/2019- 01, financed by Provincial Secretariat for Higher Education and Scientific Research.

\section{Declaration of competing interest}

The authors declare that they had no conflict of interests.

\section{References}

Aarset, B., Beckmann, S., Bigne, E., Beveridge, M., Bjorndal, T., Bunting, J., McDonagh, P., Mariojouls, C., Muir, J., Prothero, A. et al. (2004). The European consumers' understanding and perceptions of the "organic" food regime: The case of aquaculture. British Food Journal, 106, 93-105.

Aertsens, J., Verbeke, W., Mondelaers, K., Van Huylenbroeck, G. (2009). Personal determinants of organic food consumption: a review. British Food Journal, 111, 11401167.

Akram, U., Bilal, M., Tanveer, Y., Tariq, A., Wang, C. (2019) Online impulse buying of organic food: a moderated (website personality) mediation (social appeal) process. IJISCM, 11, 3-24.

Aschemann-Witzel, J., Zielke, S. (2017). Can't Buy Me Green? A Review of Consumer Perceptions of and Behavior Toward the Price of Organic Food. Journal of Consumer Affairs, 51, 211-251.

Basha, M.B., Mason, C., Shamsudin, M.F., Hussain, H.I., Salem, M.A. (2015). Consumers Attitude Towards Organic Food. Procedia Economics and Finance, 31, 444-452.

Bryła, P. (2018). Organic food online shopping in Poland. British Food Journal, 120, 1015-1027.

Drexler, D., Fiala, J., Havlíčková, A., Potůčková, A., Souček, M. (2018). The Effect of Organic Food Labels on Consumer Attention. Journal of Food Products Marketing, 24, 441455.

Dašić, G., Radosavac, A., Knežević, D., Đervida, R. (2019). Preferences of customers and improvement of production and sales of organic products in Serbia. Ekonomika poljoprivrede, 66, 127-142.

Ellison, B., Duff, B.R.L., Wang, Z., White, T.B. (2016). Putting the organic label in context: Examining the interactions between the organic label, product type, and retail outlet. Food Quality and Preference, 49, 140-150.

Fotopoulos, Ch., Krystallis, A., Ness, M. (2003). Wine produced by organic grapes in Greece: using means-end chains analysis to reveal organic buyers` purchasing motives in comparison to the non-buyers. Food Quality and Preference, 14, 549-566.
Gil, J.M., Gracia, A., Sanchez Garcia, M., Gil, J.M., Gracia, A., Sanchez Garcia, M. (2000). Market segmentation and willingness to pay for organic products in Spain. International Food and Agribusiness Management Review, 3, 1-20.

Gleim, M.R., Smith, J.S., Andrews, D., Cronin, J.J. (2013). Against the Green: A Multi-method Examination of the Barriers to Green Consumption. Journal of Retailing, 89, 44-61.

Huang, Y., Oppewal, H. (2006). Why consumers hesitate to shop online: An experimental choice analysis of grocery shopping and the role of delivery fees. International Journal of Retail \& Distribution Management, 34, 334-353.

Hughner, R.S., McDonagh, P., Prothero, A., Shultz, C.J., Stanton J. (2007). Who are organic food consumers? A compilation and review of why people purchase organic food. Journal of Consumer Behavior, 6, 94-110.

Kapuge, K.D.L.R. (2016). Determinants of Organic Food Buying Behavior: Special Reference to Organic Food Purchase Intention of Sri Lankan Customers. Procedia Food Science, 6, 303-308.

Khan, S.N., Mohsin, M. (2017). The power of emotional value: Exploring the effects of values on green product consumer choice behavior. Journal of Cleaner Production, 150, 65-74.

Lea, E., Worsley, T. (2005). Australians' organic food beliefs, demographics and values. British Food Journal, 107, 855869.

Lee, H.-J., Yun, Z.-S. (2015). Consumers' perceptions of organic food attributes and cognitive and affective attitudes as determinants of their purchase intentions toward organic food. Food Quality and Preference, 39, 259-267.

Lin, P.-C., Huang, Y.-H. (2012). The influence factors on choice behavior regarding green products based on the theory of consumption values. Journal of Cleaner Production, 22, 11-18.

Liu, C., Zheng, Y. (2019). The Predictors of Consumer Behavior in Relation to Organic Food in the Context of Food Safety Incidents: Advancing Hyper Attention Theory Within an Stimulus-Organism-Response Model. Frontiers in Psychology, 10, 2512.

Magnusson, M.K., Arvola, A., Hursti, U.-K.K., Åberg, L., Sjödén, P.-0. (2003). Choice of organic foods is related to perceived consequences for human health and to environmentally friendly behavior. Appetite, 40, 109-117.

Marian, L., Chrysochou, P., Krystallis, A., Thøgersen, J. (2014). The role of price as a product attribute in the organic food context: An exploration based on actual purchase data. Food Quality and Preference, 37, 52-60.

Morganosky, M.A., Cude, B.J. (2000). Consumer response to online grocery shopping. International Journal of Retail \& Distribution Management, 28, 17-26.

Mortimer, G., Fazal e Hasan, S., Andrews, L., Martin, J. (2016). Online grocery shopping: the impact of shopping frequency on perceived risk. The International Review of Retail, Distribution and Consumer Research, 26, 202-223.

Nagy-Pércsi, K., Fogarassy, C. (2019). Important Influencing and Decision Factors in Organic Food Purchasing in Hungary. Sustainability, 11, 6075.

Oroian, C., Safirescu, C., Harun, R., Chiciudean, G., Arion, F., Muresan, I., Bordeanu, B. (2017). Consumers' Attitudes towards Organic Products and Sustainable Development: A Case Study of Romania. Sustainability, 9, 1559.

Padel, S., Foster, C. (2005). Exploring the gap between attitudes and behaviour: Understanding why consumers buy or do not buy organic food. British Food Journal, 107, 606-625,

Park, E.J., Kim, E.Y., Funches, V.M., Foxx, W. (2012). Apparel product attributes, web browsing, and e-impulse buying on shopping websites. Journal of Business Research, 65, 1583-1589.

Pennings, J.M.E., Wansink, B., Meulenberg, M.T.G. (2002). A note on modeling consumer reactions to a crisis: The case of the mad cow disease. International Journal of Research in Marketing, 19, 91-100.

Pham, T.H., Nguyen, T.N., Phan, T.T.H., Nguyen, N.T. (2019). Evaluating the purchase behaviour of organic food by 
young consumers in an emerging market economy. Journal of Strategic Marketing, 27, 540-556.

Rahnama, H. (2017). Effect of Consumption Values on Women's Choice Behavior Toward Organic Foods: The Case of Organic Yogurt in Iran. Journal of Food Products Marketing, 23, 144-166.

Rana, J., Paul, J. (2017). Consumer behavior and purchase intention for organic food: A review and research agenda. Journal of Retailing and Consumer Services, 38, 157-165.

Reinders, M.J., Bartels, J. (2017). The roles of identity and brand equity in organic consumption behavior: Private label brands versus national brands. Journal of Brand Management, 24, 68-85.

Sreeram, A., Kesharwani, A., Desai, S. (2017). Factors affecting satisfaction and loyalty in online grocery shopping: an integrated model. Journal of Indian Business Research, 9, 107-132.

Stoleru, V., Munteanu, N., Istrate, A. (2019). Perception Towards Organic vs. Conventional Products in Romania. Sustainability, 11, 2394.

Testa, F., Sarti, S., Frey, M. (2019). Are green consumers really green? Exploring the factors behind the actual consumption of organic food products. Business Strategy and the Environment, 28, 327-338.

Venter, K., Van der Merwe, D., De Beer, H., Kempen, E., Bosman, M. (2011). Consumers' perceptions of food packaging: an exploratory investigation in Potchefstroom, South Africa: Consumer perception of food packaging. International Journal of Consumer Studies, 35, 273-281.

Wägeli, S., Janssen, M., Hamm, U. (2016). Organic consumers' preferences and willingness-to-pay for locally produced animal products: Preferences for locally produced animal products. International Journal of Consumer Studies, 40, 357-367.

Wekeza, S., Sibanda, M. (2019). Factors Influencing Consumer Purchase Intentions of Organically Grown Products in Shelly Centre, Port Shepstone, South Africa. IJERPH, 16, 956.

Zanoli, R., Naspetti, S. (2002). Consumer motivations in the purchase of organic food: A meansend approach. British Food Journal, 104, 643-653. 